\title{
Norms of Ambivalence in Setting, Plot and Point-of-View in the Anti-Realist World of Salman Rushdie and Ben Okri
}

\author{
Owoeye Durojaiye Kehinde \\ Joseph Ayo Babalola University \\ Ikeji-Arakeji, Pmb, 5006 Ilesa \\ Osun State, Nigeria \\ Tel: $+2348027249638 \quad$ E-mail: duro_eye@yahoo.co.uk
}

\begin{abstract}
"Inbetweeness", a cardinal source of strength and weakness of the colonized writer, is an indispensable element in postcoloniality, emphasizing its hybrid nature. Leaning on contextual equivocation, to the "periphery", seems to be an antidote to the certainty that the "centre" ennobles with evangelistic vigour. The transcendence-driven postcolony exploits the lithe structure of the novel genre to essay dismantling literary frontiers to reflect ideological vagueness and obscurity, which are antipodal to Western bourgeois lucidity. This article, against this background, explicates how Salman Rushdie and Ben Okri, build setting, plot and point-of-view to stem the tide of cultural subordination through imaginative contrarieties.
\end{abstract}

Keywords: Anti-realism, Decolonisation, Metastasis, Orthodoxy, Multiplicity, Ambivalence

\section{Introduction}

Bolstered by the scientistic value obsession of the triumphant bourgeoisie of the nineteenth century, colonialist realist ideology glorifies definiteness and in its conquering expeditions tries to co-opt the conquered societies roughshod into its thought-world. Conscious of the need to protect the spiritual virility of its culture, the "defeated" society embarks on an aggressive literary campaign to confute physical realism, a result of the racialization of ontological and cosmological reasoning by the custodians of Eurocentrism. Dissatisfied with the imposition of a one-sided reality on societies that celebrate the haziness in disembodied realities, the postcolony, through its authors, advances the slippery dual sensibilities of visibility and invisibility, tangibility and intangibility. Symbolically representing the dual character of the postcolony is Azaro's dilemma and predicament in being torn between keeping faith with his spirit agreement and his passionate desire to end his mother's misery as a result of his repeated going and coming. He decisively prefers the "interspace" (Okri, 1992:5). Rushdie and Okri, like many writers from the "periphery", build the "interspace" into their setting, plot and point-of-view to further the cause of mythic imagination.

The voyaging protagonist in Astonishing the Gods also confronts the numinousness (the supernatural and mysterious) in hybrid living in his ignorant quest for visibility. He is apparelled in an enchanting garb of indistinctness as he experiences mental trauma on his way to being emptied of most traces of visibility. Saleem Sinai's maternal ambiguity in Midnight's Children is used by Rushdie to project the hybrid propaganda. He (Saleem) is a child of two mothers. This dual maternal reality impacts on the channel of the plot, which leads inexorably to an unpleasant denouement: the disbandment of the midnight fraternity through Shiva's treachery. His spiritual nasal exploits, added to the aforestated, accentuate the duality that the author weaves around the character motif of Saleem. The exuberant vitality in Midnight's Children is particularly pronounced in

the vastness of its canvas [which depicts why actions] in the novel [take] place in three countries. Within just India the settings shift from Kashmir to Amritsar, Agra, Delhi and Bombay; then via a tortuous passage through war and revolution in Pakistan and Bangladesh, back to Delhi; to Benares for the apocalyptic climax and finally, for the conclusion in Bombay. None of this, of 
International Journal of Applied Linguistics \& English Literature

ISSN 2200-3592 (Print), ISSN 2200-3452 (Online)

Vol. 1 No. 6; November 2012

course, includes Saleem's telepathic tourism all over India when he first discovers his magical gift of a midnight's child. The most obvious thing about this amazingly peripatetic quality of the novel is that it places it firmly in the tradition of the picaresque novel; and the picaresque, as Bakhtin points out, is one of the clear modern heirs to the Menippean satire. (Engblom, 1994, 299)

The Moor's parentage in The Moor's Last Sigh also smacks of such double-sidedness. He is of mixed Catholic and Jewish religious backgrounds, the cognizance of which impeded and nearly stalled his parents' marriage. This may have been accursedly responsible for the "hobbledehoy" growth, thickening the imaginative texture of the work. The Satanic Verses near-absolutely wears an ambivalent plot. Setting, plot and point-of-view are on this score structured by Rushdie and Okri to, on a large scale, mirror two-facedness but with significant imaginative and narratological departures, a countenancing of Rushdie's contention that "reality is an artifact, and that it is incumbent upon writers who understand this to enter into the process of making reality" (Hassumani, 2002: 15), and the most tangible upshot of the 'making' is difference, even more noticeable in many cases than similarity. Before going deeply into how Rushdie and Okri make their setting, plot, and point-of-view a subject of the tropes of multiformity, it is important to make a short review of a few critics' observations about their fiction.

\section{Literature review}

There have manifold critical perspectives on the fiction of Salman Rushdie and Ben Okri but few of them, due to space prescription, will suffice for this exposé on some aspects of postcolonialism. Though very useful for the consummation of this paper, more profound insights into the cross-texual analysis of the setting, plot and point-of-view inclinations of the authors will contribute to expatiating upon their imaginative discretions.

Jaina Sanga discusses "the epitome of postcolonial hybridity" in Rushdie's works (Sanga, 2001: 77). He is assertive that Rushdie makes it a"powerful form of resistance not only to Western epistemology but to the subcontinent's dominant ideologies as well” (77). Sanga adverts to Edward Said's concept of hybridity which enfolds "the notions of overlapping and intertwinning" to concretise his argument about Rushdie's fiction.

John Ball finds a connection between satire and duality in postcolonial texts like Rushdie and Okri's novels. To Ball, "binary contrasts are also created by another set of assumptions in satire theories: the presence of gaps" (Ball, 2003: 21). Some of the gaps he identifies are: "the gap between what might be and what is" (21), "the discrepancy between the material and moral streams of life" (21), and "the contrast between reality and pretense" (21).

Keith Booker and M.D Fletcher also ventilate the subject of dualism in the fiction of Rushdie. Both emphasise how duality is alive in the polyphony that surrounds his works. Booker says that all of Rushdie's fiction "consistently embraces contradiction privileging the plural over the singular, the polyphonic over the monologic" (Booker, 1994: 238). Fletcher relates Rushdie's works to the satire but opines that unlike the satire, his "novels are characterised by the "unresolved dualities" of polyphonic writing, [...] a dialogic that remains in tension,that does not cancel itself out" (Fletcher, 1994: 17). Fletcher reasons that "because there is no fundamental truth to appeal to, the appropriate strategy is a plurality of presentational facts" (17), plurality being seminal to understanding Rusdie's creative genre.

"Ben Okri: Animist Realism and the Famished Road" is the title of an article in which Harry Garuba brings up ambivalence as a trope in Ben Okri's novels. Garuba contends that Okri "moves his characters between the objective world of fact and the subjective world of hallucination and dream" (Garuba, 1993" 23).

Gareth Griffith establishes the fact that Ben Okri, like his contemporaries, manifests empathy for "a renewed sense of the complexity of forces which have always operated to produce English texts in Africa [...]" (Griffiths, 2000: 309). The "complexity of forces" he highlights is the convolutions in contradictions that inundate postcolonial literature.

Olatunbosun Ogunsanwo, like other critics, recognises the idea of multiplex reality construction in Okri's fiction. Ogunsanwo is of the view that Okri's fiction radiates "multiplicity of narrative dimensions and cultural interdiscussivity" (Ogunsanwo, 1995: 41), an allusion to the aftermath of colonial relationships

Ato Quayson is effusive about the vagueness in plot-structuring in Okri's works, especially The Famished Road. He concerns himself with the a-realistic form and spirituality of temporal constructs. Quayson submits that in Okri's novels, The Famished Road in paticular, "[...] no specific time indices are given. All the time indices are vague references to "that night", "the next morning", "during that time", and so on" (Quayson, 1997: 128). 
International Journal of Applied Linguistics \& English Literature

ISSN 2200-3592 (Print), ISSN 2200-3452 (Online)

Vol. 1 No. 6; November 2012

\title{
3. Setting
}

There is an obvious amplification of the "doubleness" theory and ideological ambivalence that shape postcolonial literary contentions in the way the two authors construct setting. Rushdie's opinion on the fantastic nature of cities - cities being his primary and dominant setting in fiction - is an eye-opening preface to this discussion. He avers:

\begin{abstract}
In a city, you have endless varieties of lives which in many ways contradict each other, which one would find very hard to reconcile with each other, yet co-existing [...] That aspect of the city as being an irreconcilable space, as well as an endlessly shifting and illusory space, I think obviously is 'magical' (Reder, 2000: 104).
\end{abstract}

The section "A City Visible but Unseen" (Rushdie: 1988, 241) in The Satanic Verses speaks volumes about the issue of “doubleness”. Ato Quayson's reading of Okri's works agrees with Rushdie's supposition. On Okri's method of conceptualising setting, Quayson's impression is that "the city is postulated as having a hallucinatory effect on characters" (Quayson, 1997:102). To Rushdie, cities are invented, artificial spaces, which though look permanent and solid, are extremely ephemeral and transitory. That many of the highly contrived parts of their novels have deep roots in the real life of the characters ideally creates a convergence and divergence in the way Okri and Rushdie construct setting to suit their plot. There is an inventive difference between the two writers in respect of this question of setting. It is even plausible to affirm that construction of setting is where they seem to differ most in their fantastic fictionalizing. While Rushdie's statement can be taken as a true and absolute reflection of how he goes about creating contextual platforms for his weird world, Okri, at some juncture, goes beyond Rushdie's intermittent stay in the "spiritual clime" into the heart of Africa's overly surreal and frighteningly ritualistic culture. In their (Okri and Rushdie) own way, the psychoanalytic breaching of the boundary between the conscious and unconscious realms is perpetuated.

City-inclined, the shift, for Rushdie, to the unconscious abode in Midnight's Children is a linear, unmistakable transition. A good example is when the soldiering quartet, including Saleem, is on a chase after the Mukti Bahini, some Indian-trained Bangladeshi guerrillas. They first rove in a boat on the river Padma before moving, deliberately on the Buddha's instruction, into a jungly Sundarbans. They get into it only to be overpowered by the unreality of its logic, "the time-shifting sorcery of the forest" (423) and "insanity of the jungle" (417). They cross the frontier into the "chthonic womb" of "the terrible phantasms of the dream-forest" (417), where Ayooba, in the dark, beholds a translucent figure of a peasant with a bullet-hole in his heart and a scythe in his hand staring mournfully at him; a white wraith-like monkey with the face of his mother visits him night after night; the forest also penetrates Saleem the Buddha; a blind, translucent serpent bites him, pouring its venom into his heel but he is already immune to it, courtesy of Dr Shaapsteker's mythical association with snakes. That "the novel is shot through with a "carnival sense of the word"" (Engblom, 299) strikes a chord with the large scope given to the fantastic "[...] settings of slum naturalism [...] the slums of India [...] brothels, marketplaces, prisons, and the high road, where the most motley congeries of characters can be thrown together" (300). Indeed, in Midnight's Children, "one has entered into carnivalized space and time" (300).

With the magical jungle experience, both Okri and Rushdie are seen to traverse home and forest in the use of setting. The distinction between their applications is determined by some issues, viz. medium of ingress into the forest, the dreaminess or outlandishness of the forest, nature of their home locale and how straightforward the experience is. In The Moor's Last Sigh, Rushdie deploys a predominant home or city locus but with significant thrusts or shifts into the magical walls and canvasses of Vasco Miranda and Aurora respectively.

In some of Okri's works, the home locale is the ghetto, where squalor, disease, misery and deprivation reign, unlike Rushdie's city focus. Events, like in Rushdie, take the ordinary form. Once, Azaro in The Famished Road is led into the forest by a dog that fractures the path to his home into numerous paths. Unknowingly, he follows the path to the forest. Again, after escaping from two spirit-driven albinos, a two-legged dog leads him to the forest. However, it does assume an unusual dimension when the shift in setting is abrupt and sudden. A case in point is when he is gripped by the horror of a stinging noise in the forest. He opens his eyes to find himself in the belly of the road, where events continue undisturbed. Azaro describes the transformation: "[...] I emerged in another reality, a strange world, a path which completed its transition into a road" (Okri, 1992: 241). At its more sublime level, Azaro does talk to people at two different settings at the same time. This interlinking of settings, a clear-cut 
difference from what obtains in Rushdie's works, occurs when Azaro converses with the three-headed spirit in the air, and at the same time, but with intermission, talks with his father at home.

The interconnectedness of settings and the forest locus itself become more grotesque in Songs of Enchantment. Azaro, while viewing the world through a masquerade's eyes, finds himself locked up in his head, a mighty house, another place entirely. He also accidentally hurls himself into a blind old man's dream - another setting within the ghetto ambience - where he beholds suffering of all kinds. Okri's forest here sufficiently depicts the African mythic universe about its inhabitants - spirits, homeless ghosts, hidden gods, ritual noises, invisible trees, et cetera, all agents of "another level of time" (Okri, 1994,25) which Okri's "dreaming forest" (25) is peopled with. He describes further the forest experience:

The forest became dangerous. It became another country, a place of spectral heavings, sighs, sussurant arguments as of a council of elders, a place with fleeting visions of silver elephants and white antelopes, a place where elusive lions coughed [...] (68).

But for some Okri-imagined African ritual information, one could conclude that Rushdie's Sundarbans and Okri's forest are one and the same. Some words and phrases point out this convergence. "Dream-forest", (417) "unreality of trees", (415) "overdose of reality", (414) "time followed unknown laws", (422) "jungle of dreams", (423) "peak of delight", (422) et al, that appear in Rushdie's description of the Sundarbans in Midnight's Children enable the reader to grasp the meeting of minds of the authors.

On a final note, Okri observably uses six settings in the two novels: the ghetto naturalistic setting, the naturalistic-cum-unnaturalistic forest setting, and some other-worldly locales like the belly of the road, the air, the mind and a dream. Often, the bewildering experience does occur in a flux, that is, from Madame Koto's bar, to Black Tyger's room, to somebody's dream, to the forest, to another person's dream, moving in a cyclical and disjointed manner. Rushdie's setting imagining is, however, more easily apprehended and with little confusion. Despite Okri's penchant for setting flux, the setting in Astonishing the Gods, though may seem double to the travelling "visitor" hero when considered in psychoanalytic terms since he is said to have accessed the empyrean setting of the invisibles through dream, the transition from land to the island of the invisible phenomena, like that in Midnight's Children, is linear. That is where the likeness ends. A flux follows when he steps on the island where transformatory realities keeps him disturbingly confusedly enchanted by the unusualness of the environment. Setting here can be said to be wavy because the hallucinatory experience of the "visitor" takes him from one locus to another without his physically walking into them. He finds himself, though stuck, in many places. The one place in which he is stuck, in most cases, continues to transform into different places.

Rushdie also imposes some form of ambiguity on setting in The Satanic Verses. Merging the airy space with the predominant earthy context is decisive in his realism-disuniting fiction and he does not temporize in his offensive as the main characters have to make a descent onto terra firma very early in the prose. The air-and-land coupling becomes a pungent protest device when Gibreel, with the phantasmal manifestation of Rekha, violates the realistic sanctity of the English air for hours on end.

\section{Plot}

The exegesis of plot formation by the two authors as it relates to some of their novels shows some clear difference, for "the human element, the personality of the historiographer, disrupts the very project of attaining an objective account of the past. By its foregrounding of the subjective twist to any rendering of the past, historiographic metafiction draws the logical conclusion from this paradox" (Banerjee, 2002: 166). Contextualization and personalized fictive representation of the past may have been responsible for the two authors' plot construction difference despite both writing 'magical'. The structural haziness, formlessness, or even chaos that Rushdie imposes on the plot of The Satanic Verses is an ideological premeditation to confute realist tropes of clarity, visibility, continuity and conformity, a conglomeration of which supports "the fixity of identity" (Sanga, 83), a philosophical supposition that draws the ire of the repressed, colonized mind. This is a preterite appeal to the modernist revolt against traditional literary forms that were the foundations of Western Civilization and culture before the First World War - a civilization that presupposes social coherence and stability in the obvious face of futility and anarchy that is not only "contemporary history" but also continuous history.

A palatable equivalent of the non-Western incoherence that is described above is embedded in the pre-historic culture of the colonized, very much recuperable in a contemporary analysis of postcolonial literature. These 
elements of discontinuity in cultural exposition of the postcolony now create an identity cleavage between it and the Western norm of order, presenting postcolonial writers with the opportunistic postmodernist instrument to launch aggressive affronts against the "master perspective" on its literary frontier. Many of Rushdie's works, particularly The Satanic Verses, is a monumental actualization of the paradox that turns "sameness into difference" (quoted in Sanga, 84) due to its concentric thematic all-inclusiveness which whirls through examination, re-examination, self-examination and cross-examination. Its plot, on that score, very much realizes Robert Young's oxymoronic suggestion that "hybridity makes difference into sameness, and sameness into difference, but in a way that makes the same no longer the same, and the different no longer simply different" (quoted in Sanga, $84)$, in which case, "sameness and difference are always already deconstructed" (84).

The creed of "sameness and difference" is definitely a pointer to the centrifugal norms that are characteristic of the ambivalence in which the postcolony is enfolded. Since this novel evinces some form of disunity pursuant to interrogating the Western sense of wholesomeness, the ordering of events tends to defy an understandable appreciation of meaning - that is, it is not that straightforward. In the first place, it is evident in the double plotting. There is the main plot and some other subplots, although one must reiterate that the plots share affinities in the profound ventilation of postcolonial ethics of exile, journey, struggle and other motifs. The main plot is the journeying of Gibreel, and to a lesser degree that of Chamcha, as they attempt to expose the limits and limitations of English realism. It encompasses the miraculous safety of both after the Bostan tragedy, which triggers their near endless sojourn into the depth of hybridity in the heart of singularity. However, the main plot would stand on shaky grounds without the support of some subplots - one of which is the Jahilian ridicule of Mahound and his monotheistic ideals, the context of which raises the pluralist profile of Gibreel. Another subplot is Alleluia Cone's obsession with Mount Everest, a shade of the flight motif, which also accentuates the transcendence-driven philosophy of Gibreel's a-Englishness.

With the existence of a double-plotting arrangement, the ground seems prepared not for a linear plot - which is agreeable to the proponents of realism - but for a winding, convoluted plot construction course, which is in accord with the hybridity of the novel's postcolonial image. In a work of realism, the plot arrangement is in many cases straightforward, starting from exposition, to complication, to climax, and finally to denouement. On the contrary, the magical realist antagonistic fiction idealizes the reverse, as events in the spiritual clime do not permit limpidity of any definition. The plot in The Satanic Verses embodies the philosophy of power navigating the whole wide spectrum of a society, for events oscillate like a pendulum, avoiding any permanent "presence". The novel starts from the end, for the end of the plot is known from the beginning. The ending of the novel is the sanctification of metastasis and plurality; and right from the start, there is no hiding that slant. In other words, the work opens with the denouement, and to exacerbate issues, it is difficult to explain when the complication arises, much less when a climactic point is reached.

Plot construction in Midnight's Children is a doctrinaire reflection of advancing the cause of multiplicity. The lay-out evidences the plurivocal consciousness of the writer and the complexity-laden picture of India's socio-political structure. Events in the novel traverse three plot arrangements viz: episodic, organic and convoluted; "the narrative structure [...] seems almost intentionally designed to violate the kind of smooth temporal progression that is central not only to Wilhelm Meister but to the European bildungsroman as a whole; [indeed,] much of the plot is driven by accident and coincidence rather than by logic and cause and effect" (Booker, 1999: 171). Its episodic outlook is vividly presented by the chronology of events, the chapterized pattern of the autobiographer's history and most pungently by the analysis of activities in the life of the narrator before he is born up to his thirty-first birthday when the whole story ends. Its organic construct has its essence in the parentage of Saleem Sinai, the narrator, which keeps being influenced by every other event. The convoluted frame is brought into being not only by Saleem's chaotic growth, as he is inclined to reminisce on his past, which he acquiesces invariably affects his future, but also by the spectral presence of his country's history in his, which is filled with revolting pictures of social indelicacy in the ugly political engineering of Prime Minister Indira Ghandi, the brutal murder of Mian Abdullah, cases of marital infidelity, et cetera. This work specifically "navigates a complicated course between the metaphoric and the literal, between inclusive Menippean optimism and exclusive negative satiric optimism" (Ball, 135).

The episodic structure suggestively produces a linear plot. In this linearity, the complexity is made more profound; the multiple plot design projects the profundity. What becomes extant is linearity enclosed in complexity, one with intricately-webbed events. In other words, there are multiple sub-plots running concurrently with the main plot, desiringly constructed to achieve a structural unity so as to negate some agents of realistic singularity who aver, to the contrary, that unity is difficult without singularity. The main plot is built on the chequered companionship of 
Saleem Sinai with India. Saleem says "he had been mysteriously handcuffed to history, my destinies indissolubly chained to those of my country" (Rushdie, 2000: 3). Prime Minister Nehru writes in part:

You are the newest face of that India which is also eternally young. We shall be watching over your life with the closest attention; it will be, in a sense, the mirror of our own. (139)

Saleem affirms it: "For the next three decades, there was to be no escape". (3) The Saleem-India umbilical relationship is, to put it mildly, very grisly. With the benefit of hindsight, Saleem describes his birth "at the precise instant of India's arrival at independence" as "the benighted moment" (3), a morphological premonition of dread, which is in evidence in the argument that

[...] Midnight has many children: the offspring of independence were not all human. Violence, corruption, poverty, generals, chaos, greed $[. .$.$] I had to go into exile to learn that the children of midnight$ were more varied than I - even I - had dreamed. (333)

As earlier stated, the main plot is the propinquity of Saleem's fate with India's, a connection that pushes the narrator into the "clutches of the active-metaphorical mode of connection" (332). The connections are myriad: the defeat of India by Chinese forces at Thag La ridge occurs the night the children of midnight launched a concerted assault on Saleem (341); India's attack on China under cover of artillery happened when Saleem's "nasal passages were in a state of acute crisis" (344); Saleem was responsible for triggering off the violence which ended with the partition of the state of Bombay when he related an abuse rhyme sung in Marathi by a Maharashtra pupil with which he (the pupil) used to bully Gujarati boys, to Gujaratis (219); Parvati returned to the magicians's ghetto when an explosion blew an Indian Cabinet Minister "into the history books" (476); while mysterious assassins killed government officials, "the magicians' ghetto concentrated on another mystery: the ballooning basket of Parvati-the-witch" (478); and "while Major Shiva [Saleem's birth rival] reeled from whore to whore, the Indira Congress was reeling too" (474). The untoward list of the synchronous issues of coming into being of activities concerning Saleem and the Indian state seems endless.

The singularity-frustrating course of the plot is charted through many sub-plots, one of which is Tai the boatman's episode. Tai's connection to Saleem's story is of fundamental importance as he is the person who reveals the mythical power of Saleem's nose, the structure of which is genealogically present in the Sinai family. The story of the perforated sheet is another sub-plot. It raises very quickly in the plot the question of culturality, cultural identity and rootlessness. It brings to light Aadam Aziz's (Saleem's grandfather's) long absence from his cultural roots, having gone to study medicine in Germany, bowing to the influence of "Heideberg [...] Ingrid [...] Oscar and Ilse Lubin the anarchists" (6). Ghani, a self-confessed culturalist, tells him "You see, I am a lover of culture" (14), thereby issuing mordant strictures to chastise Aadam's debased Indianness.

Hence the perforated sheet divide between Aadam and the girl could be likened to a wall between the West and Ghani's Indian culture. The optimism epidemic (47) of Mian Abdullah, the anti-partitionist, is central to understanding the crisis in the multilingual build of India. His death - and by extension the death of the optimism - supposedly at the hands of The Muslim League is a gory reflection of the Indian débâcle that Saleem is mirroring. These are just few of the subplots, all indispensable ancillaries in the development of the main plot.

The opening statements in The Moor's Last Sigh and some brief momentary comments by the narrator before continuing his story, as he says, after the death of his father (Abraham Zogoiby) (106), may tempt a critic to hastily conclude that the novel has a convoluted plot. One is especially forced to reason like this because the narrator pauses at some junctures to tell some related tales before he progresses with the main tale. A further reading negates the winding plot viewpoint. The opening page provides a hint of how events are terminated in the Benengeli "mad fortress" (3) of Vasco Miranda with the expectation that the plot will wear a front-back prosodic picture. A more comprehensive look would result in an acknowledgment that the narrative is a foreshadowing of the adventures, misadventures, misfortune, adversity, shock and ultimately catastrophe that dominate relationships between the characters. Realistically, plot development in the work does not, surprisingly though, attract the byzanthine structure that Rushdie's Midnight's Children and The Satanic Verses have. It is indeed "unRushdean" for any of his postmodern prose works to be as intelligible and plain as the movement of events in The Moor's Last 
Sigh seems to suggest. The linear course of actions coupled with a high degree of organic connectivity between them enhances the luminousness.

Aurora is the incontrovertible character that captures most the reader's zest. Almost every interaction that matters is purposed towards illuminating the epical but tragic nature of her transcendental art. There is no divagation from that pursuit. Her child, Moraes, is informed that "to be the offspring of our daemonic Aurora [...] is to be, truly, a modern Lucifer. [...] son of the blooming morning". (5) Right from the weird disquiet that plagues her da Gama paternal clan through her own execrable nuclear Zogoiby family, either "Auroraphobia" or "Auroramania" is the talk or thought of the moment. Her colossal presence bestrides the Cochin universe with undiminished pervasiveness. Her fiery temperament is unleashed on almost every character that she has contact with, Epifania, her paternal grandmother, being the most noticeable in this regard.

Epifania's curse on her is, of course, in some measure or degree, the substructure of the plot. Aurora, goaded by her fiendish indiscretion, feverishly works towards the actualization of Epifania's "hard fall" execration. The imprecation assumes a pestilential and epidemic proportion within her nuclear family. Her family is afflicted with profane deaths - a constant abnormality in the da Gama fraternal order. She (Aurora), two of her three daughters, Ina and Mynah, and her husband (Abraham) meet cruel deaths. Aurora loses Minnie, the second daughter, to a nunnery, the latter having abandoned her parents' atheism. Aurora fumes at her when she (Minnie) goes on hunger strike because her mother fails to understand the reason for her action. Minnie is, equally, later a fatal victim of Abraham's "Samson's" option - the bombing that brings down many facilities in Bombay - when he (Abraham) discovers his invisibility game is up. Aurora's only son, Moraes, suffers from an abnormal growth. He confesses: "I am going through time faster than I should [...] I, Moraes Zogoiby, known as Moor, am [...] a man living double-quick" (143). He goes further: "We have been a cussed lot, we da Gama-Zogoibys" (212).

The Francisco-Epifania-Camoens-Aires crisis-ridden dynasty, Vasco Miranda's venomous introduction into the conflict, Moraes' somatic disorder, Reverend Oliver D'Aeth's erotic fantasising, Uma Sarasvati's love affair with Moraes, the Abas Alli Baig scandal, Abraham's abhorrent myth of invisibility et al are some of the key stories in the plot in which Aurora is deeply involved. Despite being a polemicist, the narrator is quick to acquaint readers of part of her virtues:

I ask you to consider that in spite of all her freethinking bohemian ways, Aurora Zogoiby was still, in some deep recess of her heart, a woman of her generation, a generation that would find such behaviour [Abraham's infidelities] tolerable, even normal, in a man; whose womenfolk shrugged off their pain, burying it beneath banalities about the nature of the beast and its need, periodically, to scratch an itch (222) (Emphasis not mine)

The narrator provides in the quote a philosophical but paradoxical judgment on the intermittent descent into brutishness by the human species. The cohabitation of the good and the bad in Aurora parallels Leela Ghandi's critique of the colonizer-colonized fraternal relationship in postcolonial identity theorizing. To her, "postnationalism pursues [...] indeterminacies in the colonial encounter to bridge the old divide between Westerner and native through a considerably less embattled - if more politically amorphous - account of colonialism as a cooperative venture" (quoted in Ball, 171). Postcolonial fiction is, therefore, ironically portrayed as a regenerative system that "seeks to show how the colonizer encounter contributed to the mutual transformation of colonizer and colonized" (Ball, 171). In essence, transcultural valuative symbiosis between the two is energized, putting to sleep the ungainly bellicose rhetoric that earlier created a wedge between them.

Plot ordering in Ben Okri's The Famished Road and Songs of Enchantment bears similar sequences, the latter being a partial sequel to the former. The sequences are the linear and organic plot build-ups, but less of the organic because any of the parts can be severed without appreciable damage to the overall realization of the author's ideological and philosophical pursuits. The linear conduit is established to make Azaro, the prime character in the two prose works, define himself, despite intimidating forces. To aid his self-definition motive, Ben Okri places him on the journey scape, both physically and metaphorically, with every element in the plot directly or indirectly related to the preternatural hero's quest intents, which are moral, ideological and socio-political. The contributions of Black Tyger, Jeremiah the photographer, Madam Koto and some supernatural characters are a miniature of the larger visions of Azaro: to give vigour to the veracity of the reality of "unreality" and to promote social stability and sanity. 
That Astonishing the Gods has a linear frame is an unvarnished truth. The protagonist's travel is purposed towards making him cognizant of the opportunities in "invisibility". The clarity in the linearity of the plot is traceable to the fact that the hero, to realise his paradoxical objective, has to move from one defined point to another, and at every point, he has to hurdle over some prepared obstacles, which include some characters, most of them invisible. The cause-and-effect chronology is so made up that the stumbling blocks are in form of tests - supervised by guides that must be passed; there must be success in one before he is allowed to proceed to the other. He is expected to journey from the "strange port" (5) of the invisibles through the impedimenta to the "great convocation" (12). If he gets there - which he does ideationally - he will be seen to have succeeded. In his peregrination, he does not go back. He is "forward-looking", the truthfulness of which underscores the straight-line profile and non-complexity of the plot. The protagonist's course from the port to the "great convocation" is a phased obstacle race. The obstacle race is supervised by nine paranormal guides. In other words, every guide represents a hurdle to be crossed.

Between these 'guided' phases, the visitor is forced to imbibe all the ideals that will make him to realize "[...] THE DREAM OF THE INVISIBLES", which is "TO CREATE THE FIRST UNIVERSAL CIVILISATION OF JUSTICE AND LOVE” (155).

\section{Point of View}

Escaping from an undignifying living bracket, coupled with a transcendentalist inventiveness to advance the cause of selfhood, is constitutive in neocolonial decolonization fiction. In many respects, there exists some uniformity in the way Okri and Rushdie go about this. They start by deploying the first-person narrator point-of-view for ideological reasons, taking advantage of "the paradox of its apparently [...] solid and objective nature" (Brigg, 1994: 177) after all "first-person narrators are ideal battlegrounds for the paranoia question, with the added advantage that the reader cannot circumvent the narrator to get any other view of reality" (177).

Ironically, in some textual contexts, the first-person narrator tries to involve the reader and the "surrogate reader" in the pursuit of, not the truth, but the confirmation of the truth of his/her narration. Saleem's symbiotic relationship with Padma in Midnight's Children particularly projects the self-confessed narrator's unreliability; Padma serves to lighten up his memory in moments of amnesia. Rushdie speaks of his (Saleem's) errant nature: "This is why I made my narrator, Saleem, suspect in his narration; his mistakes are the mistakes of a fallible memory compounded by quirks of character and of circumstance, and his vision is fragmentary". (quoted in Wilson, 1994: 58). In this respect, the disordered sequence in parts of the plot is understood. Paradoxically, however, this Padma eidetic usefulness contradicts the narrator-cum-author fractured sense of putting down stories. The first-person narrator is clear about this: "But here is Padma at my elbow, bullying me back into the world of linear narrative, the universe of what happened next" (quoted in Wilson, 59). Though Saleem delights in the narrative assist of Padma, he is not unmindful of the ambivalence that he desires: "How to do without her paradoxical earthiness of spirit, which keeps - kept? - my feet on the ground [...] but must I now become reconciled to the narrow one dimensionality of a straight line?" (quoted in Wilson, 59).

After even acknowledging the supportive strength of Padma on her return, in "I am balanced once more - the base of my isosceles triangle is secure. I hover at the apex, above present and past" (quoted in Wilson, 60), he is disturbed at being taken down from the apex of the point-of-view ladder, to be on even keel with the reader-surrogate. The unconsummated marriage between the narrator and Padma is symbolically perpendicular to the passionate quest of the former to rise above creative perpendicularity. Of course, Saleem and Padma's narrative difference epitomizes antipodal historiographies, which "become "alternative" merely in the sense of their joyful self-immersion into a pool of infinite variety, relativism and historical playfulness" (Banerjee, 2002: 165). These notions of "self-immersion" and "historical playfulness" notwithstanding, some sense of cultural concreteness may have inspired them. Wole Soyinka's Ogunnian metaphysics in "The Fourth Stage" for instance creates a tableau of the Yoruba contradiction-laden, fragmentary cultural dialectics.

Although not a conscious attempt to proclaim the authorial voice, the first person initiative, to a large extent, serves the protest purpose of these authors; the bottled-up anger within them is forced out through him. Rushdie agrees: "[...] then, inevitably, a chunk of your experience and your attitudes and your feelings and passions will come out through his mouth and will come out through his experience" (Reder, 206). Making it a point of interest, he concurs that " $[\ldots]$ the character of Aurora, the painter, even though she is a girl, has some of my ideas [...] that's to say she's an encyclopaedic painter $(206,207)$. She tries to put the world on her canvas. Rushdie digresses in the last quoted sentence to amplify the notion of the-author-in-the-character; after all Aurora in The Moor's Last Sigh is not the narrator. 
However, apart from the seepage of the author's passions into the first-person narrator, Saleem (the first-person narrator) enables the author to have a controlling grip on reality; he makes and re-makes to suit his world-view. In any event, he is embroiled in a romantic reality contest with an antagonistic force, and he has to mobilize every literary medium to imaginatively subdue an adversarial ideological view-point. Fructifying this aim he perfects through the near omniscient functioning of the first-person narrator. Azaro, being the first-person narratorial voice in both The Famished Road and Songs of Enchantment, takes the reader deeply into how and why the unborn child "remained indifferent to the long joyless parturition of mothers". Moraes Zogoiby, "The Moor" of The Moor's Last Sigh, with his narratorial advantage, is able to exhaustively penetrate the psyche of his mother, Aurora, from whose actions the grave unnaturalism of his family genetically impacts tragically and artistically positively on the plot. In Midnight's Children, the "I" first-person pronominal system introduces the reader into the highly personalized autobiography of Saleem Sinai, whose character inclusiveness generates a rhetorical understanding of the plurivocal platform on which post-modernists ply their literary trade. The narrator's position is unique in that he professes that he thrives on this all-inclusiveness. The first-person is, above all, inspired by "the need to effect a working relationship between narrator and listener which will stand up to their conflicting priorities" (Wilson, 1994: 59).

In Astonishing the Gods contrarily, the third-person option is adopted, and this is for a particularly unique reason in the identity quest of the visitor. It is to place the visitor absolutely at the mercy of the transforming forces. This unmitigated control over his being makes him very submissive, like an obsequious entity, to the horrors of self-dissolution that he experiences towards self-apprehension. All the characters, animate and inanimate, are created for the fulfillment of the prophecies concerning the visitor's mutation from the visible to an invisible. For the purpose of clarification, these animate and inanimate characters are not narrators; they are created to fulfill the objective of the third-person narrator, that is, to instill in the visitor the benefits of invisibility.

For the purpose of propagating the pluralist ideology in The Satanic Verses, Rushdie explores disruptive narratorial sequence to invigorate his affront to realist convention of clarity. He seems to be very comfortable with the tropes of complicatedness as demonstrated in Booker's rumination:

\begin{abstract}
$[\ldots]$ the palinodic mode of narration (reminiscent of Samuel Becket) serves to heighten the confusion of the reader. Faced with the choice between so and not so, real and not real, the reader is thwarted in his efforts to reach a comfortable situation. Such either-or, yes-no choices are constantly subverted within Rushdie's overall assault on polar logic. This manipulative mode of narration is another Rushdie trademark - his work tends to feature unreliable, intrusive narrators who openly break the frame of the fiction to reveal the processes of composition, disturbing any attempts at naturalistic recuperation of those fictions [...] (Booker, 1994, 246).
\end{abstract}

There is the mix of both the preponderant third-person narrator and the first-person narrative device. Since the work is firmly entrenched in revolutionary idealism, the third-person perspective enables authorial intrusion, in which case the author comes in at regular intervals to dictate the course of events with comments on the norms of newness, transcendentalism, change, et cetera. In respect of the first person, its ideational purpose is to invigorate the identity objective of Gibreel, investing the main character in particular with the prowess to explain his mythical ambivalence. This first-person narrative voice finds comfort deep in the midst of an on-going third-person voice without any informative punctuation sign to signal the linguistic interference. This interweaving of the narrative voices is, however, intermittent but its effect on the plot is immediately recognizable during Gibreel's hospitalization after accidentally taking a punch on the jaw during a filming session.

The tactical structural flux takes the shape of the following narratorial style: the third person point-of-view narrative technique is interwoven intermittently with the first-person narrative idiom but without any organised use of punctuation marks, like the inverted comma, to create some degree of clarity. In other words, the highly marginally deployed first-person narratorial voice plunges intrusively into the dominant third-person scheme. Examples of this abound in the plot.

Example one:

The Grandee lolls in his bedroom while concubines attend to his needs. Coconut oil for his thinning hair, wine for his palate, tongues 
International Journal of Applied Linguistics \& English Literature

ISSN 2200-3592 (Print), ISSN 2200-3452 (Online)

Vol. 1 No. 6; November 2012

for his delight. The boy was right. Why do I fear Mahound? He begins, idly, to count the concubines, gives up at fifteen with a flap of his hand. The boy. Hind will go on seeing him, obviously; what chance does he have against her will? (Rushdie, 1988: 101) (Emphasis not mine).

Example two:

"No, Abu Simbel reflects, the boy Baal was wrong, these men are worth our time. Why do I fear Mahound?" (102)

Example three:

"Enough God, his unspoken words demanded, why must I die [...]" (30)

Example four:

\begin{abstract}
But when he has rested he enters a different sort of sleep, a sort of not-sleep, the condition he calls his listening, and he feels a dragging pain in the gut [...] and now Gibreel, who has been hovering-above-looking-down, feels a confusion, who am I, in these moments it begins to seem the archangel is actually inside the prophet, I am the dragging in the gut, I am the angel being extruded from the sleeper's navel, I emerge, Gibreel Farishta, while my other self, Mahound, lies listening (110) (Emphasis not mine).
\end{abstract}

An analysis of the four narrative samples reveals the genre of indistinctiveness that permeates the point-of-view discourse. In the first, one identifies a fluid connection, devoid of any adherence to conventionalism in the use of punctuation - conventionalism and orthodoxy being the victim of the author's fictive campaign - from the authorial voice to the first person. The intrusive third-person narrator is in control from "The" to "delight", (101) when the ruminating Grandee comes in to interrogate the necessity of fearing Mahound - immediately after which the limiting voice of the third person is heard commenting on the quoted but unquoted Grandee. Again, without identifying with the regulatory quotation marks but continuing on the first person's parallel voice, the Grandee talks, concluding that aspect of the omniscient narratorial function. The italics in the quoted passage are used to dismiss the orthodox monotheism of Mahound, emphasizing "Rushdie's attacks on the authority of texts and his attacks on the authority of religion" (Booker, 247).

The second sample presents an even more complicated discoursal picture. While the first sample identifies the quoted voice through italicizing, the second readily confuses the reader by muddling up the voices of the third person and the subject, allowing the third person to grammatically swallow up the reflecting but obscurely and implicitly quoted Simbel. The third sample is also a blend of the voices of the third person and the subject.

Not oblivious of the lack of foundation for the obscurity in the first two samples, the fourth sample quickly presages the undercurrents of its own opacity. The spirituality that dictates events in the dark void, or the gulf that exists between the conscious, subconscious and unconscious realms, identifiably underscores the fluvial transition of the omniscient narrative voice into the subject's. This spirituality is adequately enabled by a "not-sleep" type of sleep - a state that shares contextual contiguity with Freudian "subconscious", where the wide chasm between the conscious and the unconscious regions of the psyche is narrowed to a more touchable, malleable and tangible phenomenon. So pliable in this circumstance is the unconscious that the third person narrator, Gibreel and the prophet are locked up in the quest for conversational substantiality, recognition, or supremacy along syntactic lines.

One can pick out three voices: that of the narrator; Gibreel's, which rams probably uninvitedly into the third person's; and the covert struggle-for-prominence voice of Gibreel's other self, prophet Mahound, which lays an ambuscade for his rival Gibreel. The vagueness in narratorial device is clearly communicated when Gibreel confirms that not only that "we [the prophet and he] flow in both directions along the umbilical cord" but also that " $[\ldots]$ he listens to the listening which is also an asking" (Rushdie, 1988: 110), bringing into stylistic view the interrogatively self-reflecting concern of Simbel in the first sample and Gibreel's apprehensive self-apprehension quest in the third, all in the face of the prophet's intimidating monologic orthodoxy; the result is a concentric 
displacement of one by the other along an open-ended narratorial chain. Italicizing in this cited instance visualizes the dual nature of Gibreel.

The mazy pattern of the narrative also acquires some conviction in the influx of dialogues into the mainstream of the third person point-of-view voice, with open disdain for the rules of grammar that give order to such intrusions. Although at a point the author uses italics to distil the dialogue, he delves into a more unconventional mode when he allows a duologic outburst into the narrative heart of the third person without any informative delineation of it as a quoted statement. The following exemplifies it:

By the end of the call Pamela Chamcha, normally the most controlled of women, who locked herself in a bathroom when she wanted to cry, was shrieking down the line, for God's sake, woman, will you shut up with your little good-samaritan speeches and listen to what I am saying? Finally she slammed down the receiver and rounded on Jumpy Joshy, who saw the expression in her eyes [...] (178)

The italicized statement is introduced to fracture the continuity, albeit selfishly, that realists exhort, and break the conventionality of realists' cognition of sentence structuring, where the narrator and the subject are conspicuously set apart with strict punctuation order.

Due to the purposive inclination towards a labyrinthine literary texture in the text's point-of-view, the structuring of the plot is decidedly a reflection of disorder, and in some cases it enhances a clear sense of order, depending on the analytical tool being engaged, exemplifying the functionality of ambiguity in postcolonialism. At the level of ideology and meaning, there seems to be a clear-cut movement towards a unity of action, an artistic whole, or organicity. The ideologizing in the novel is geared towards empowering a sort of de-centring, as opposed to the existence of a centre that controls and guides as to what meaning should be; in which case the ideology of multiplicity or multidimensionality, especially as coursed through the magical realist thought-view, is projected.

From the beginning, through the middle, to the end, there is a consistency, a unified sense of direction, in the pursuit of magnifying and rationalizing mutative sensibilities and the creed of transcendence. From the two main characters - Gibreel and Chamcha - to other ancillary characters like Rekka Merchant, Alleluia Cone, Rosa Diamond, Ayesha of the butterfly myth, the denizens of Jahilia, et al, there is a connective tissue of transformative sloganeering that binds them, albeit Gibreel is the nucleus of the multifacetedness. Where there seems to be a fallible narrator like Prophet Mahound, who professes a contrary, monofocal ideology, he is quickly brought down to earth by the author's satirical reproach to the extent that he accepts the polyglossic compromise. Gibreel buries Mahound's absolutist mono-culturality: "I'm saying nothing. Don't ask me to clear things up one way or the other; the time of revelations is long gone" (Quoted in Booker, 1994: 247).

\section{Conclusion}

Ambivalence as a trope distances the postcolony from the ideological specificity that marks the emergence of the Western bourgeoisie. This illuminates the cultural contrariety which acts as a wall between the proselytizing guest and its disagreeing host. Rushdie and Okri, active agents in the struggle against neo-imperialist rationalist and empiricist values, express this disagreement through the magical disruption of Western conventional literary ethos to validate cultural heterogeneity. Okri's dualist susceptibilities, in spite of the fact that some of his novels evince nebulousness and norms of multiformity, are low-profiled in setting, plot and point-of-view compared to Rushdie's. Rushdie seems to be more combative in all the three elements than Okri, whose leaning towards multifocal fiction is most apprehended in setting construction. Even where the two authors mellow down their mythic paradoxicality, rays of two-sidedness would appear below its façade of intelligibility, thereby reinforcing the more the impotence of bourgeois realism in an environment that is peculiarly supernaturalist. Admittedly, some degree of artificiality may exist in the two authors' postmodern fiction (artificiality is an attribute of all fictive constructs), elements of culture-inspired naturality underpin their imaginativeness. Aware of the creative instinct that creates imaginative writing, postmodern fiction goes beyond the absoluteness in realistic orthodoxy to “expose its [postmodernism's] signifying process, to explode metanarratives" (Hassumani, 15), especially in its attempt to co-opt nonessentialism and "strategic essentialism" (15) into its rhetorical treatise. 
International Journal of Applied Linguistics \& English Literature

ISSN 2200-3592 (Print), ISSN 2200-3452 (Online)

Vol. 1 No. 6; November 2012

\section{References}

Ball.J.C. (2003) Satire and the Postcolonial Novel. New York: Routledge.

Banerjee, M. (2002) The Chutneyfication of History. C.Winter: Universitätsverlag.

Booker, M. K. (1994) "Beauty and the Beast: Dualism as Despotism in the Fiction of Salman Rushdie" in Reading Rushdie: Perspectives on the Fiction of Salman Rushdie. Fletcher, D.M. (ed.) Amsterdam: Rodopi.

Booker, M. K. (1999) Critical Essays on Salman Rushdie. New York: G. K. Hall \& Co.

Brigg, P. (1994) “Salman Rushdie's Novels: The Disorder in Fantastic Order.” in Reading Rushdie: Perspectives on the Fiction of Salman Rushdie. Fletcher, D.M. (ed.) Amsterdam: Rodopi.

Engblom, P. (1994) "A Multitude of Voices: Carnivalization and Dialogicality in the Novels of Salman Rushdie" in Reading Rushdie: Perspectives on the Fiction of Salman Rushdie. Fletcher, D.M. (ed.) Amsterdam: Rodopi.

Garuba, H. (1993). "Ben Okri: Animist Realism and the Famished Genre”, in The Guardian, Lagos.

Griffiths, Gareth. (2000). African Literatures in English: East and West. Essex: Pearson Education Ltd.

Hassumani, S. (2002) Salman Rushdie: A Postmodern Reading of his Major Works. Associated University Presses: London.

Fletcher, M.D. (1994) "Introduction” in Reading Rushdie: Perspectives on the Fiction of Salman Rushdie. Fletcher, D.M. (ed.) Amsterdam: Rodopi.

Ogunsanwo, O. (1995). "Intertextuality and Postcolonial Literature in Ben Okri's The Famished Road”. Research in African Literatures, 1(26).

Okri, B. (1992) The Famished Road. London: Vintage Books Ltd. (1994) Songs of Enchantment. London: Vintage Books Ltd.

(1995) Astonishing the Gods. London: Phoenix House.

Reder, M. (ed.) (2000) Conversations with Salman Rushdie. Jackson: University Press of Mississipi.

Rushdie, S. (1988) The Satanic Verses. Delaware: The Consortium, Inc.

. (1994) The Moor's Last Sigh. London: Vintage Books Ltd.

(2000) Midnight's Children. New York: Penguin Books Ltd.

Sanga, J.C. (2001) Salman Rushdie's Postcolonial Metaphors. London: Greenwood Press.

Quayson, Ato. (1997) Strategic Transformations in Nigerian Writing. Bloomington \&. Indianapolis: Indiana University Press.

Wilson, K. (1994) “Midnight's Children and Reader Responsibility” in Reading Rushdie: Perspectives on the Fiction of Salman Rushdie. Fletcher, D.M. (ed.) Amsterdam: Rodopi. 